\title{
PENDAMPINGAN DAN PENGEMBANGAN KERAJINAN ANYAM KHAS MELAYU PESISIR DI PANTAI CERMIN PROPINSI SUMATERA UTARA
}

\author{
Irfandi $^{1)}$, Mukti Hamjah Harahap ${ }^{2)}$, Deo Demonta Panggabean ${ }^{3)}$, Dedy Husrizal \\ Syah $^{4)}$, Muhammad Al Qamari ${ }^{5}$ \\ Universitas Negeri Medan ${ }^{1,2,3)}$ \\ Universitas Negeri Medan ${ }^{4)}$ \\ Universitas Muhammadiyah Sumatera Utara ${ }^{5)}$ \\ Email: irfandi@ unimed.ac.id ${ }^{1)}$
}

\begin{abstract}
ABSTRAK
Tujuan Program pengabdian ini adalah pengabdi membantu usaha kelompok pengerajin Anyaman dan Aksesoris Khas Melayu Pesisir Pantai cermin dalam meningkatkan Pengetahuan dan Keterampilan Kelompok dapat mengembangkan usaha dan dapt mensejahterakan anggota. Selain itu meningkatkan kualitas dan kuantitas produk serta variasi produk tanpa menghilangkan ke khasan produk budaya pesisir pantai cermin. Dan yang tidak kalah penting pemasaran yang sangat terbatas pada konsep tradisional tak banyak dapat mendongkrak penghasilan dan perkembangan usaha meraka. Kedua kelompok ini saling membahu dalam mengerjakan orderan yang ada pada masing-masing kelompoknya. Metode yang dilakukan dalam mewujudkan hal tersebut diatas tim menyusun program dalam bentuk transfer ilmu dan pendampingan yang berkelanjutan. target Pertama di targetkan dalam program yaitu: praktik, pelatihan dan pendampingan peningkatan kualitas mutu produk menjadi disertai sistem pembukuan dan penggunaan TTG nya. Sedangkan Kedua mulai didaftarkan merek serta pemasaran online dan pendampingan manajemen usaha. Selanjutnya di ke-Tiga mulai membangun kerjasama dengan pemerintah dan swasta untuk persiapan produk menjdi ikon unggulan daerah serta penguata pada bidang koperasi dan BUMDES. Kegiatan ini direncanakan dilakukan dengan pendekatan Metode Pelatihan, Pendampingan pendidikan, penyuluhan, pelatihan produksi, pelatihan manajemen usaha dan rancang bangun alat.
\end{abstract}

Kata Kunci: Kerajinan, Pemasaran, TTG

\begin{abstract}
The purpose of this dedication program is to serve the business of the Malay Coasters' distinctive Webbing and Accessories craftsmanship group in enhancing Group Knowledge and Skills to develop businesses and to prosper the members. In addition, it improves the quality and quantity of products and product variations without eliminating the typical mirror coastal products. And that is no less important marketing that is very limited to traditional concepts can not boost up their income and business development. The two groups worked together to work on the orders that were in each group. The methods carried out in realizing this above the team compiled a program in the form of knowledge transfer and ongoing assistance. The first target is targeted in the program, namely: practice, training and assistance to improve the quality of product quality to be accompanied by a bookkeeping system and use of the TTG. Whereas both brands began to be registered as well as online marketing and business management assistance. Furthermore, in the Third, it began to build cooperation with the government and the private sector for product preparation to become the regional leading icon and the supervisor in the field of cooperatives and BUMDES. This activity is planned to be carried out with the Training Method approach, educational assistance, counseling, production training, business management training and tool design.
\end{abstract}

Keywords: Crafts, Marketing, TTG 


\section{PENDAHULUAN}

Luas Wilayah Kecamatan Pantai Cermin sebesar $80.30 \mathrm{Km} 2$. Wilayah terbesar pada desa Celawan sebesar $19.65 \mathrm{Km}^{2}$ atau 24.48 persen dari luas kecamatan Pantai Cermin. Ibukota Kecamatan berada di desa Kuala Lama. Kota Pari merupakan desa terluas kedua seluas $10.40 \mathrm{Km}^{2}$ yang merupakan desa yang terjauh dari kantor Kecamatan sejauh 8.0 $\mathrm{km}$. Sementara Desa yang mempunyai luas wilayah terkecil Adalah Desa Pematang Kasih dengan Luas Wilayah sebesar 1.63 $\mathrm{Km}^{2}$ atau hanya 2.03 persen dari luas Kecamatan Pantai Cermin. (Tim Penyusun BPS Serdang Bedagai, 2015).

Secara umum desa dipantai cermin merupakan daerah pesisir yang banyak ditumbuhi tanaman pandan. Dimana tanaman pandan merupakan bahan baku dalam menganyam dan daerah tersebut. Kecamatan pantai cermin pernah menerima Upakarti dengan kategori "Jasa Pelestarian Produk Seni dan Budaya Tradisional" pada tahun 2007, yang mewakili Propinsi Sumatera Utara. Dimana Kecamatan Pantai Cermin merupakan lokasi pusat pelestarian produk anyaman pandan di Kabupaten Serdang Bedagai. Dari data yang ada Jumlah Industri Rumah Tangga Anyaman Tikar di Kecamatan Pantai Cermin cukup besar dalam 1 desa bisa mencapai 303 Pengerajin bila dilihat secara umum se-Kecamatan pantai cermin ada 825 Jumlah Industri Rumah Tangga Anyaman Tikar. Yang kesemua pengerajin yang terdiri dari ibu-ibu dan anak gadis serta janda menyumbang $50 \%$ lebih dari hasil pendapatan menganyam yang kebanyakan suami mereka adalah nelayan, petani dan buruh
(Lubis, Eva Miranda. 2011). Kelompok Mitra 1 adalah kelompok UPPKS Ibu Berkarya yang dipimpin oleh Ibu Eva Mawarni bergerak dalam usaha aneka kerajinan anyaman pandan. Kelompok ini berada di Dusun III, Desa Pantai Cermin Kanan, Kecamatan Pantai Cermin, Kabupaten Serdang Bedagai. Daerah ini kaya akan tanaman pandan yang dijadikan sebagai bahan baku usahanya. Kelompok ini berangggotakan $23 \mathrm{ibu}$ rumah tangga yang terampil dalam mengolah pandan menjadi berbagai produk, seperti tikar pandan, sandal, dompet, kipas, tas, dan aneka souvenir. Pada tahun 2016 kelompok ibu berkarya masuk nominasi pada Pameran dan lomba Produk Unggulan UMKM Sumatera Utara. Proses produksinya masih menggunakan peralatan tradisional, akan tetapi mereka dapat menghasilkan 40 lembar tikar, 300 sendal, 75 dompet, 50 buah tas dan souvenir dalam satu bulan. Masingmasing produk dijual sesuai dengan ukuran dan bentuknya pada kisaran (Rp 100.000 sampai dengan Rp 800.000), dimana tikar pandan ada empat jenis, yang pertama berukuran $(1,5 \mathrm{~m} \times 0,6 \mathrm{~m}),(2 \mathrm{~m} \times 1,75 \mathrm{~m}),(3 \mathrm{~m} \times$ $3 \mathrm{~m})$ dan ukuran pesanan. Sendal dengan ukuran S,M dan L dijual dengan harga Rp 20.000). Dompet dijual pada kisaran harga (Rp 10.000 sampai dengan Rp 130.000), sedangkan tas dijual pada kisaran harga (Rp 180.000 sampai dengan Rp 375.000). Mereka banyak mengalami kendala dalam pemasaran, manajemen keuangan, Pembukuan Usaha, dan TTG. Saat ini pemasaran produk di sekitar Sumatera Utara dan sekali keluar daerah. Demikian juga dengan proses produksi yang masih rendah, menjadi 
kendala ketika menerima orderan dalan partai besar. Manajemen pengeloaan yang masih tradisional turut memperlambat laju pertumbuhannya. Kelompok mitra 2 adalah kelompok UMKM Kria Pandan yang diketuai oleh Ibu Maidirita yang beralamat di Pantai Cermin Kiri Kecamatan Pantai Cermin bergerak khusus produksi tikar pandan. Kelompok ini beranggotakan 8 orang, juga masih banyak mengalami dalam mengembangkan usahanya. Kendala yang dihadapi adalah peralatan yang masih manual dan peningkatan kualitas desain produknya perlu mendapatkan pembinaan berkelanjutan. Kelompok Sehati yang beranggotakan 10 orang dipimpin oleh Ibu Sri Rahayu bergerak dalam usaha yang sama yang beralamat Desa Pantai cermin kiri. Pemasaran yang sangat terbatas pada konsep tradisional tak banyak dapat mendongkrak penghasilan dan perkembangan usaha meraka. Ketiga kelompok ini saling membahu dalam mengerjakan orderan yang ada pada masing-masing kelompoknya.

Langkah lain yang sering mereka lakukan adalah sering mengikuti pameran di berbagai daerah untuk mempromosikan hasil produknya. Usaha kerajinan di kecamatan pantai cermin memang cukup dikenal karena daerah pentai cermin merupakan daerah wisata bahari yang terkenal sampai ke negara tetangga Malaysia dan Singapura. Dan sangat padat apabila pada harihari libur maupun weekend. Usaha kecil kerajinan kedua mitra cukup banyak diminati oleh para turis lokal maupun negara tetangga karena ke khasan citra melayu pesisir melekat pada produk seni mereka selain itu kedua kelompok aktif mengikuti pameran yang diadakan oleh Pemerintahan kabupaten maupun pemerintah Provinsi Sumatera Utara.

\section{METODE PELAKSANAAN}

Untuk mencapai tujuan dari kegiatan ini metode yang digunakan adalah Pelatihan dan Pendampingan kepada pengrajin anyaman Khas Melayu Pesisir. Selanjutnya Metode Pelatihan dan Pendampingan kegiatan serta manfaat dan outputnya dalam setiap tahun berjalan dapat dilihat seperti tabel berikut ini:

Tabel 1. Kegiatan, Manfaat serta Output

\begin{tabular}{lll}
\hline \multicolumn{1}{c}{ Kegiatan } & \multicolumn{1}{c}{ Manfaat } & \multicolumn{1}{c}{ Output } \\
\hline Perbaikan mutu & $\bullet$ Kelompok & $\bullet$ Produk yang \\
produk melalui & kerajian anyam & berkualitas \\
kegiatan pelatihan & memiliki & dan standart \\
dan pendampingan & produk yang & $\bullet$ Produk \\
kreatifitas produk & berkualitas & dengan \\
dan pengembangan & $\bullet$ Memiliki variasi & model yang \\
model & model yang & bervariasi, \\
& terbaru dan & modren dan \\
& kekinian & kekinian \\
\hline Perbaikan Proses & $\bullet$ Pengeringan & $\bullet$ Terpal \\
Bahan dengan & produk dapat & penyerap \\
menggunakan alas & optimal karena & panas \\
\hline
\end{tabular}




\begin{tabular}{|c|c|c|}
\hline $\begin{array}{l}\text { dari bahan dan } \\
\text { warna bahan yang } \\
\text { menyerap panas } \\
\text { secara optimal }\end{array}$ & $\begin{array}{l}\text { tingkat keringan } \\
\text { bahan } \\
\text { mempengaruhi } \\
\text { kualitas } \\
\text { - Proses } \\
\text { pengumpulan } \\
\text { bahan baku } \\
\text { lebih mudah dan } \\
\text { tidak tercecer } \\
\text { - Kebersihan dan } \\
\text { sterilitas produk } \\
\text { dapat terjaga }\end{array}$ & $\begin{array}{l}\text { sebagai alas } \\
\text { bahan } \\
\text { produk } \\
\text { - Produk yang } \\
\text { bersih, } \\
\text { kering } \\
\text { maksimal } \\
\text { dan } \\
\text { berkualitas } \\
\text { baik }\end{array}$ \\
\hline $\begin{array}{l}\text { Perbaikan proses } \\
\text { pemipihan bahan } \\
\text { dengan } \\
\text { menggunakan TTG } \\
\text { alat pemipih bahan } \\
\text { sehingga bahan } \\
\text { dapat pipih dan } \\
\text { memenuhi standart } \\
\text { ketebalan (Ridwan } \\
\text { AS, 2013) }\end{array}$ & $\begin{array}{l}\text { - Bahan dapat } \\
\text { pipih secara } \\
\text { standart dengan } \\
\text { ketebalan yang } \\
\text { sama sehingga } \\
\text { produksi lebih } \\
\text { cepat } \\
\text { - Tidak banyak } \\
\text { memakan } \\
\text { tenaga manusia } \\
\text { serta } \\
\text { menghemat } \\
\text { waktu } \\
\text { pengerjaan }\end{array}$ & $\begin{array}{l}\text { - Alat } \\
\text { teknologi } \\
\text { tepat guna } \\
\text { mesin } \\
\text { pemipih } \\
\text { purun dan } \\
\text { pandan } \\
\text { - Bahan } \\
\text { dengan } \\
\text { ketebalan } \\
\text { standart } \\
\text { serta } \\
\text { berkualitas }\end{array}$ \\
\hline $\begin{array}{lr}\text { Perbaikan } & \text { Proses } \\
\text { Pewarnaan } & \text { Produk } \\
\text { Dengan } & \text { Hasil } \\
\text { Warna Yang Tahan } \\
\text { Lama Dan Melekat } \\
\text { Kuat ( Tim Bidang } \\
\text { Ilmu Seni LIPPI, } \\
\text { 2013) }\end{array}$ & $\begin{array}{l}\text { - Proses } \\
\text { pewarnaan } \\
\text { dapat berjalan } \\
\text { secara maksimal } \\
\text { tidak di letakkan } \\
\text { pada ember } \\
\text { plastik } \\
\text { - Kelompok } \\
\text { pengerajin dapat } \\
\text { langsung } \\
\text { melakukan } \\
\text { pencampuran } \\
\text { dan pemanasan } \\
\text { warna di } 1 \\
\text { wadah }\end{array}$ & $\begin{array}{l}\text { - Alat } \\
\text { teknologi } \\
\text { tepat guna } \\
\text { pencampur } \\
\text { warna } \\
\text { berbahan } \\
\text { stainess } \\
\text { style } \\
\text { - Produk } \\
\text { dengan hasil } \\
\text { pewarnaan } \\
\text { yang } \\
\text { maksimal }\end{array}$ \\
\hline $\begin{array}{l}\text { ndekatan Program } \\
\text { yang ditawa } \\
\text { kan Masalah }\end{array}$ & $\begin{array}{l}\text { dihadapi } \\
\text { sebagai } t \\
\text { Peningk } \\
\text { pengeml }\end{array}$ & $\begin{array}{l}\text { oleh kedua mitra adalah } \\
\text { berikut: } \\
\text { atan } \\
\text { bangan }\end{array}$ \\
\hline $\begin{array}{l}\text { Pendekatan Progr } \\
\text { ama tiga tahun un } \\
\text { permasalahan y }\end{array}$ & $\begin{array}{l}\text { Produk } \\
\text { handycr } \\
\text { Pantai C }\end{array}$ & $\begin{array}{l}\text { kerajinan anyaman dan } \\
\text { aft khas melayu Pesisir } \\
\text { Cermin }\end{array}$ \\
\hline
\end{tabular}




\section{a. Persiapan}

Pada tahapan ini akan dilakukan pendataan peserta pelatihan dai kedua mitra yaitu kelompok UPPKS Ibu berkarya dan Kelompok UPPKS Kria Pandan

\section{b. Pelaksanaan}

1) Melaksanakan pendampingan

Pelatihan dan kualitas produk, peningkatan

2) Kegiatan pelatihan dan pendampingan kreatifitas produk dan pengembangan variasi model yang modren dan kekinian tanpa meninggalkan ke khasan anyaman melayu pesisir.

3) Melaksanakan pelatihan dan pendampingan Manajemen standarisasi bahan baku dan tinggkat kekeringan dan kebersihan bahan baku penjemuran dengan alas yang steril dan menyerap panas menggunakan alas dari bahan dan warna bahan yang menyerap panas secara optimal pada saat penjemuran sehingga kebersihan serta mutu bahan terjaga.

4) Pelatihan dan pendampingan Proses pewarnaan Produk dengan hasil warna yang tahan lama dan melekat kuat.

\section{c. Evaluasi}

Evaluasi pelaksanaan kegiatan tentang pelatihan dan pendampingan peningkatan Mutu dan pengembangan variasi bentuk Produk kerajinan anyaman dan handycraft khas melayu Pesisir Pantai Cermin

Prosedur Kerja untuk Mendukung Realisasi Metode yang Ditawarkan Prosedur kerja untuk mendukung realisasi metode yang ditawarkan tersebut.

\section{Prosedur Kerja untuk Mendukung Realisasi Metode yang Ditawarkan \\ Prosedur kerja untuk mendukung realisasi metode yang ditawarkan tersebut dapat dilihat seperti skema diagram alir berikut ini:}

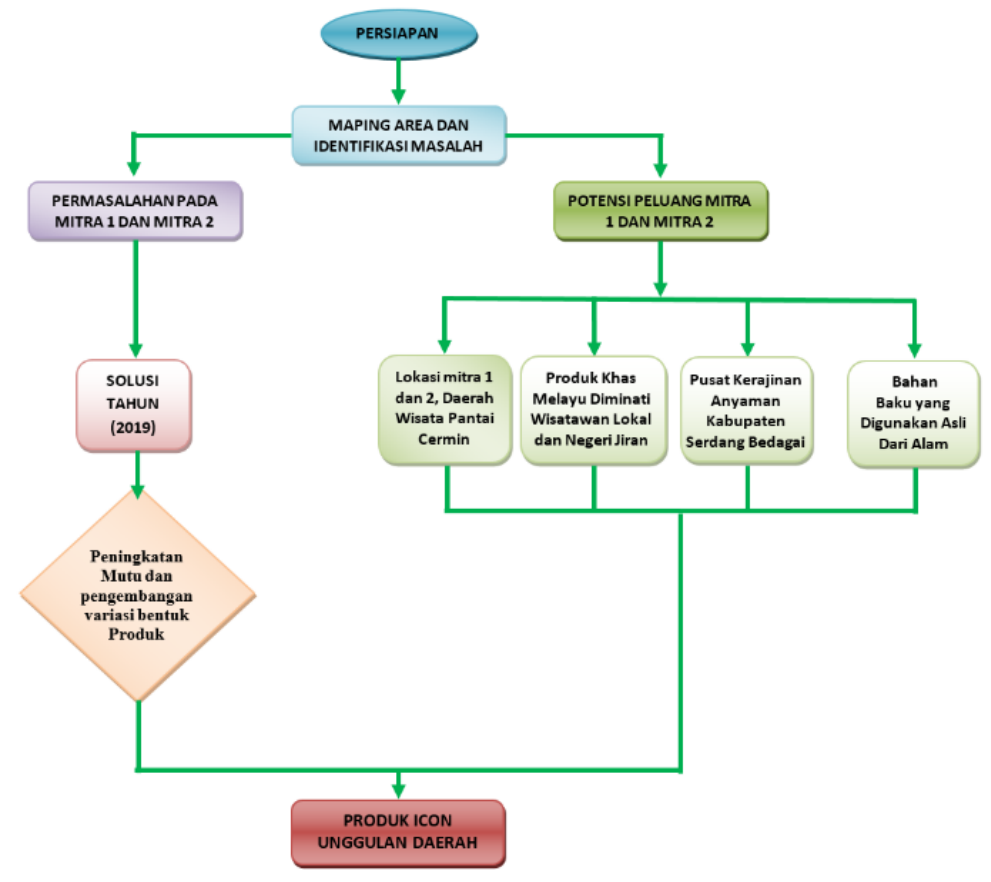

Gambar .1. Skema Prosedur Kerja Realisasi Metode yang ditawarkan (Irfandi, I., Hidayat, T., \& Azis, A. C. K., 2018) 


\section{HASIL DAN PEMBAHASAN \\ Lokasi}

Kegiatan pengabdian kepada masyarakat ini dilaksanakan di rumah warga kelompok kerajinan anyaman pandan khas pesisir melayu pantai cermin serta di Balai Pertemuan Warga Desa Pantai Cermin Kanan Kecamatan Pantai Cermin Kabupaten Serdang Bedagai.

\section{Pelaksanaan Kegiatan}

Pelatihan

Manajemen

Administrasi dan Pembukuan Keuangan Kerajinan Anyam Khas Melayu Pesisir di Pantai Cermin Propinsi Sumatera Utara ini telah dilaksanakan. Adapun kegiatankegiatan yang telah dilakukan meliputi tahapan sebagai berikut:

\section{Persiapan}

a. Persiapan (koordinator tim pelaksana dengan LPM dan Usaha mitra).

b. Tim pengabdi melakukan Pengurusan perijinan kepada aparatur Desa Pantai Cermin Kanan yang dijadikan lokasi pengabdian.

c. Ketua tim bersama anggota pengabdi melakukan Penyusunan jadwal kegiatan dan melakukan pembagian kerja

\section{Operasional Kegiatan}

a. Tim pengabdi melakukan Temu usaha untuk pemantapan kegiatan

b. Pengumpulan bahan dan peralatan yang dibutuhkan dalam kegiatan Kelompok Usaha

c. Penyajian Materi I Pengetahuan dan perkembangan produk Anyaman peningkatan kualitas

d. Penyajian Materi II Peningkatan Inovasi dan kreasi produk

e. Pelatihan III Peningkatan jumlah produksi dengan menggunakan mesin penggiling/ Pemipih. f. Pelatihan desain kemasan dan pembukuan dan Pelatihan pembukuan dan administrasi Usaha. (Irfandi, I., Hidayat, T., \& Salman, R. 2018)

g. Pelatihan Pemasaran secara Online dengan membuat e-mail, media sosial Blog untuk memasarkan produk. (Irfandi, I, 2014)

\section{Evaluasi dan Pemantauan}

Kegiatan pemantauan dan evaluasi dilakukan untuk mengetahui sejauh mana keberhasilan kegiatan dapat tercapai. Evaluasi dilakukan pada saat pelaksanaan kegiatan baik diawal, proses kegiatan berlangsung dan setelah kegiatan selesai dilakukan. Kegiatan pemantauaan dilakukan dengan menggunakan pengamatan langsung terhadap pola, model, proses dan hasil kegiatan yang dilaksanakan dengan data yang diperoleh secara deskriftif dengan persentase, skor penilaian:

$$
\begin{array}{ll}
- & >80=\text { Sangat Baik } \\
- & 70-79=\text { Baik } \\
- & 60-69=\text { Cukup } \\
- & <60 \quad=\text { Kurang (Irfandi, } \\
& 2018)
\end{array}
$$

\section{Evaluasi awal kegiatan}

Tempat kegiatan peningkatan kualitas produk anyaman, dilaksanakan di rumah seorang Ketua kelompok kria pandan Usaha Kerajinan Anyaman Pandan khas melayu Pesisir Pantai Cermin, rumah tersebut sangat sesuai sebagai tempat pelatihan hal disebabkan luasnya ruangan untuk melakukan Pendampingan dan Penyuluhan tentang proses pengolahan produk, Higienitas, Kerapihan serta inovasi dan kreasi pengembangan produk khas melayu yang di kombinasikan dengan bahan-bahan modren serta 
budaya-budaya etnik yang lain dapat dilihat bahwa kelompok antusias untuk mengembangkan produk dengan kreativitas masing-masing kelompok dan dan anggota kelompok mampu memperkenalkan Produk Produk khas melayu pesisir pantai cermin menjadi produk yang berimprovisasi dengan produk modren dan kekinian sehingga kegiatan. Sebelum kegiatan dilaksanakan tim terlebih dahulu mempersiapkan alat dan bahan yang akan dipergunakan untuk pembuatan produk-produk anyaman pandan khas pesisir pantai cermin.

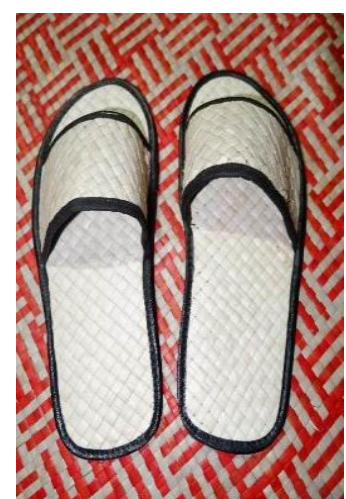

(2)

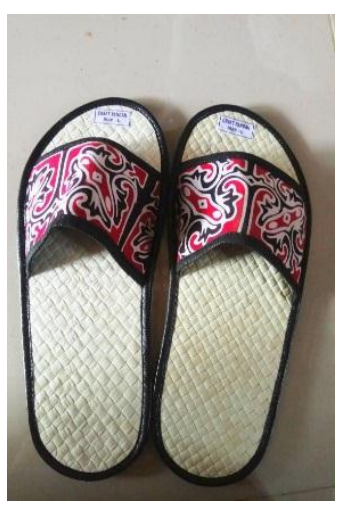

(3)

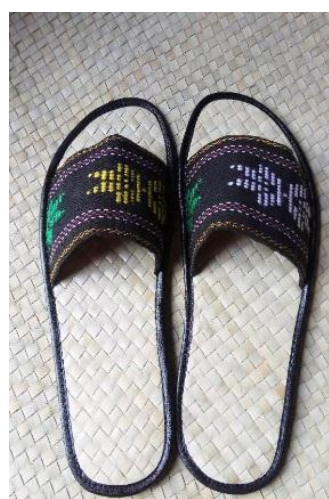

(4)

Gambar 2 Motif Sendal Pandan yang biasa di Produksi

Gambar 3 Motif Sendal Pandan Kombinasi Dengan Motif Ulos

Gambar 4 Motif Sendal Pandan di Kombinasikan dengan Batik Batak

\section{Evaluasi Pasca Pemberian Bantuan Alat}

Alat-alat yang diberikan kepada mitra sesuai dengan kebutuhan dan keinginan mitra dilapangan yaitu: Mesin Pembelah pandan, mesin pemipih pandan, mesin penghalus pandan, serta wadah pemanas bahan pandan dan pencampur warna pada bahan pembuatan produk Olahan Pandan. Indikator keberhasilan kegiatan dapat dilihat ketika setelah selesai kegiatan dilakukan. Menurut Irfandi, I., Ritonga, W., \& Sabani, S. (2015), pembimbingan yang dilakukan dalam mendampingi kelompok adalah membimbing kelompok UMKM tersebut untuk bisa memahami penggunaan alat-alat produksi yang berbasis teknologi tepat guna, yang secara tidak langsung membantu pengembangan dalam hal kwalitas dan kwantitas produksi yang dilakukan.

Evaluasi dilakukan dengan pemantauan selama 1 bulan selesai kegiatan untuk melihat kelanjutan dari kegiatan ini dimana peserta kegiatan sudah memanfaatkan bantuan alat yang diperoleh dari pengabdi yang diberikan kepada masing-masing kelompok. Setelah diberikan alat tersebut tampak perubahan yang signifikan pada UMKM yang dibina tersebut. Pada saat belum dilaksanakan pembinaan UMKM Perajin anyaman pandan khas pantai cermin biasanya dapat membelah dan memipihkan pandan hanya 1 Ikat Pandan dalam 3 hari (1 Ikat $= \pm 200$ daun Pandan dengan panjang $150 \mathrm{~cm}$ ), dengan mengunakan alat pembelah dan pemipih pandan minimal 3 Ikat pandan dalam satu harinya. Dengan 
diberikannya alat perebus dan pencampur warna pandan peningkatan jumlah produk semangkin meningkat, biasanya dengan perebus yang terbuat dari kaleng cat bekas hanya dapat merebus sebanyak $3 \mathrm{~kg} /$ hari dengan alat perebus dan pencampur warna yang terbuat dari stainlesssteel dapat merebus dan mencampurkan warna sebanyak $15 \mathrm{~kg}$ / hari dengan kualitas rebusan yang maksimal serta pewarna sisa rebusan dapat digunakan kembali. Dengan bertambahnya produksi maka berbanding lurus dengan pertambahan pendapatan penjualan yang dilakukan bila ada pesanan dalam jumlah banyak atau partai besar maka UMKM Kerajinan Anyaman Khas Pantai Cermin mampu untuk memenuhinya. Biasanya dalam 1 bulan perkelompok mendapatkan rata-rata omset sebesar Rp. 17.000.000,setelah diberikan alat teknologi tepat guna terjadi peningkatan sebesar Rp. 26.000.000,- Setiap bulannya. Dan peningkatan pesanan juga semangkin bertambah seperti orderan ucapan terima kasih pada pesta pernikahan Bupati Sergai, seminar kit pada seminar nasional sebuah Universitas Besar di kota Medan, seminar kit pada Pelatihan Guru di Dharmas Raya Sumatera Barat, Seminar kit pelatihan guru di Kabupaten Sergai dan masih banyak lagi.

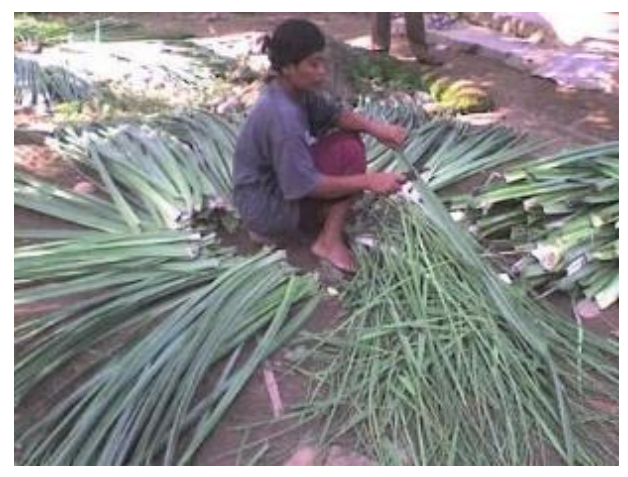

Gambar 5. Pembelahan pandan secara manual

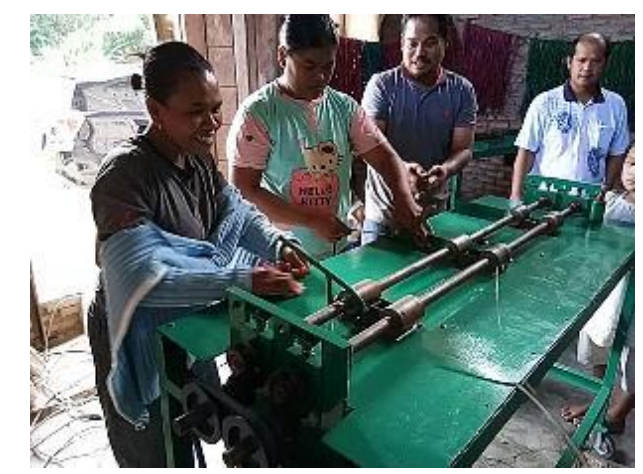

Gambar 6. Pembelahan pandan menggunakan mesin

Untuk lebih jelanya dalam hal pengembangan usaha dan tingkat keberhasilan kegiatan dapat dilihat pada tabel dibawah ini: 
Tabel 2. Indikator Perubahan Usaha

\begin{tabular}{|c|c|c|}
\hline Indikator & Awal & Akhir \\
\hline $\begin{array}{l}\text { Dengan diberikan } \\
\text { pelatihan Promosi } \\
\text { pemasaran }\end{array}$ & $\begin{array}{l}\text { Pemasaran hanya } \\
\text { disekitar lingkungan } \\
\text { Sumatera Utara }\end{array}$ & $\begin{array}{lr}\text { Pemasaran } & \text { sudah } \\
\text { Menjangkau } & \text { lintas } \\
\text { Provinsi } & \text { hingga } \\
\text { sampai Ke bali }\end{array}$ \\
\hline $\begin{array}{l}\text { Pelatihan } \\
\text { Peningkatan mutu } \\
\text { dan inovasi }\end{array}$ & $\begin{array}{l}\text { Produk hanya berupa } \\
\text { Anyaman biasa dengan } \\
\text { pewarnaan seadanya }\end{array}$ & $\begin{array}{l}\text { Produk } \\
\text { menggunakan } \\
\text { pewarnaan yang } \\
\text { lebih kekinian dan } \\
\text { dikombinasikan } \\
\text { dengan bahan-bahan } \\
\text { etnik budaya yang } \\
\text { lain dengan } \\
\text { kombinasi seperti } \\
\text { Ulos batak, Batik } \\
\text { medan dan batik } \\
\text { batak melayu }\end{array}$ \\
\hline $\begin{array}{l}\text { Dengan diberikan } \\
\text { Mesin pemipih dan } \\
\text { pembelah pandan }\end{array}$ & $\begin{array}{l}\text { Hanya dapat membelah } \\
\text { dan memipihkan } \\
\text { produk sebanyak } 1 \text { ikat } \\
\text { dalam 3 hari }\end{array}$ & $\begin{array}{l}\text { Dapat membelah dan } \\
\text { memipihkan pandan } \\
\text { sebanyak } 3 \text { ikat } \\
\text { dalam } 1 \text { hari }\end{array}$ \\
\hline $\begin{array}{l}\text { Dengan diberikan } \\
\text { pelatihan } \\
\text { Manajemen } \\
\text { Administrasi Usaha } \\
\text { dan Pembukuan } \\
\text { Keuangan }\end{array}$ & $\begin{array}{l}\text { usaha dilakukan dengan } \\
\text { manjemen keluargaan } \\
\text { dan berbasis saling } \\
\text { percaya serta keuangan } \\
\text { tidak tercatat rapi }\end{array}$ & $\begin{array}{lr}\text { usaha dijalankan } \\
\text { dengan } \\
\text { menggunakan } \\
\text { manajemen } & \text { yang } \\
\text { terpimpin } & \text { dengan } \\
\text { adanya } & \text { ketua, } \\
\text { sekertaris } & \text { dan } \\
\text { bendahara } & \text { serta } \\
\text { pembagian } & \text { kerja } \\
\text { sudah tanpak jelas }\end{array}$ \\
\hline $\begin{array}{l}\text { Setelah diberikan } \\
\text { alat pemanas dan } \\
\text { pencampuir warna } \\
\text { dengan bahan } \\
\text { stailess steel dan } \\
\text { kompor bertekanan } \\
\text { tinggi }\end{array}$ & $\begin{array}{l}\text { Hanya dapat merebus } 3 \\
\text { kg dalam } 1 \text { hari }\end{array}$ & $\begin{array}{l}\text { Dapat merebus dan } \\
\text { mencampur warna } \\
\text { sebanyak } 15 \quad \mathrm{~kg} \\
\text { dalam } 1 \text { hari }\end{array}$ \\
\hline $\begin{array}{l}\text { Omset usaha } \\
\text { perbualan }\end{array}$ & Rp. 17.000.000,- & Rp. 26.000.000,- \\
\hline
\end{tabular}




\section{KESIMPULAN}

Berdasarkan hasil kegiatan PPPUD Kerajinan Anyam Khas Melayu Pesisir Di Pantai Cermin Propinsi Sumatera Utara di Desa Pantai Cermin Kanan Kecamatan Pantai Cermin Kabupaten Serdang Bedagai, yang telah dilaksanakan maka dapat disimpulkan sebagai berikut:

1. Peserta kegiatan telah memiliki pengetahuan dan Keterampilan tentang Pendampingan dan Penyuluhan tentang Pengembangan, Peningkatan, Kreasi dan Inovasi Anyaman Khas Pesisir Pantai Cermin yang meliputi: a).Pemilihan bahan produksi b).Kebersihan dan sterilitas bahan baku produk c).Kebersihan dan sterilitas alat d).Kerapian produk anyaman. e).Inovasi dan kreasi produk f).Pengolahan Produk Sisa setelah produksi. Rata - rata mendapatkan nilai sangat baik sekali atau pointnya lebih besar dari 80

2. Untuk Pelatihan Manajemen Usaha yang memiliki kompetensi Sangat Baik (> 80) hanya 8 orang ataupun $21 \%$ dari jumlah seluruh peserta dan pada pelatihan pembukuan keuangan Usaha terdapat 7 orang atau $18 \%$ yang memiliki kopetensi sangat baik. Untuk kompetensi Baik (70-79) pada pelatihan Pelatihan Manajemen Usaha sebanyak 8 Orang atau $21 \%$ dan pada pelatihan pembukuan cukup signifikan yaitu 16 Orang atau sebesar $\quad 42 \% \quad$ memiliki kompetensi baik.

3. Untuk kompetensi Cukup (6069) dari tabel dapat kita lihat pada Pelatihan Manajemen Usaha sebanyak 18 Orang ataupun $47 \%$ dari jumlah peserta dan ini angka tertinggi pada pelatihan ini, sedangkan pada pelatihan pembukuan keuangan Usaha terdapat 14 orang dengan kompetensi cukup. Dan terakhir peserta dengan kriteria Kurang (<60) pada Pelatihan Manajemen Usaha sebanyak 4 Orang atau $11 \%$ dan untuk pelatihan Pembukuan Keuangan Usaha sebanyak 1 Orang atau $3 \%$.

4. Kepada pemerintah setempat untuk dapat berpartisipasi aktif dalam mengembangkan usaha masyarakat sehingga masyarakat lebih sejahtera berbasis ekonomi rakyat.

5. Kepada DRPM Dikti untuk dapat melanjutkan program untuk tahun selanjutnya sesuai dengan aspirasi dan keinginan masyarakat mitra.

\section{UCAPAN TERIMAKASIH}

Terima kasih disampaikan kepada DRPM (Direktorat Riset dan Pengabdian Masyarakat)

Kementerian Riset Teknologi dan Pendidikan Tinggi yang telah memberikan support Pendanaan pada Program Pengabdian Kepada Masyarakat dengan skema Program Pengembangan Produk Unggulan Daerah di Pesisir Pantai Cermin.

\section{REFERENSI}

Irfandi, I., Hidayat, T., \& Salman, R. (2018). Pemberdayaan Usaha Kecil Menengah Kuliner Roti di Kabupaten Simalungun. Jurnal Pengabdian Kepada Masyarakat, 24(2), 661-670

Irfandi, I., Ritonga, W., \& Sabani, S. (2015). Pemberdayaan UPPKS Bintang Kecamatan Batang Kuis Berbasis Teknologi Tepat 
Guna. Jurnal Pengabdian

Kepada Masyarakat, 21(82), 53-59

Irfandi, I. (2014). Peningkatan Pendapatan Anggota

Kelompok UPPKS Manalagi Kecamatan Bilah Hulu Labuhan Batu Dengan Menggunakan Oven Serbaguna. Jurnal Pengabdian Kepada Masyarakat, 21(80), 33-38

Irfandi, I., Hidayat, T., \& Azis, A. C. K. (2018). Optimalisasi Manajemen Administrasi Dan Pembukuan Keuangan Pengerajin Anyam Khas Melayu Pesisir Pantai Cermin. Prosiding PKM-CSR, 1, 16101619.
Lubis, Eva Miranda. 2011. Analisis Pendapatan Anyaman Pandan dan Sumbangannya Terhadap Total Pendapatan Keluarga. Departemen Agribisnis, Fakultas Pertanian. Universitas Sumatera Utara, Medan

Ridwan, A. S. 2013. Pembinaan Masyarakat Berbasis IPTEKS, Ciptapustaka Media Perintis, Bandung

Tim Bidang Ilmu Seni LIPPI, 2013. Pusat Dokumentasi dan Informasi Ilmiah-Lembaga Ilmu Pengetahuan Indonesia PDII-LIPI. LIPPI. Jakarta

Tim penyusun BPS Serdang Bedagai, 2015. Pantai Cermin Dalam Angka 2015. Badan Pusat Statistik Kabupaten Serdang Bedagai. 